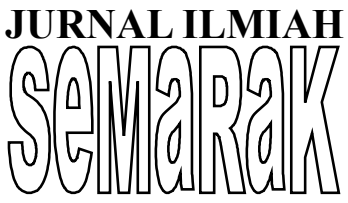

P-ISSN 2615-6849, E-ISSN 2622-3686

Jurnal Semarak,Vol. 2,No.2, Juni 2019, Hal (124- 143)

(a)Prodi Manajemen Fakultas Ekonomi Universitas Pamulang

\title{
ANALISIS TINGKAT KEPUASAN PELANGGAN PADA PELAYANAN JASA \\ TEKNOLOGI,STUDI KASUS PADA BALAI BESAR TEKNOLOGI KEKUATAN STRUKTUR - BADAN PENGKAJIAN DAN PENERAPAN TEKNOLOGI (B2TKS-BPPT)
}

\author{
BAMBANG PURNOMO Y, ST, M.Si \\ E mail : bbpurnomo61@gmail.com
}

\begin{abstract}
ABSTRAK
Kepuasan Pelanggan (Customer Satisfaction) merupakan hal yang sangat menarik untuk diangkat oleh suatu Instansi Pemerintah seperti B2TKS - BPPT, di dalam usahanya untuk memenangkan persaingan dengan instansi yang lain. Tujuan dari penelitian ini adalah bagaimana persepsi pelanggan terhadap pelayanan dan apakah kualitas pelayanan yang diberikan B2TKS - BPPTtelah memenuhi harapan pelanggan.Metode yang dipakai pada penelitian ini adalah pendekatan kuantitatif yang kemudian didukung oleh pendekatan dan data-data kualitatif. Dalam penelitian inidigunakan kuisioner yang telah ditentukan dan didisain dalam bentuk-bentuk pertanyaan Persepsi dan Harapan Pelanggan. Dimensi pertanyaan ada 5 yaitu:tangibles,empathy,reliability,assurancedanresponsiveness. Populasi kuesioner berjumlah 112 perusahaan pelanggan dan untuk mendapatkan data yang representatif, maka 87 perusahaan dijadikan sampel.Hasil penelitianmenunjukkanbahwapersepsiresponden yang menerimapelayanan yang diberikan oleh Kantor B2TKS - BPPTdinilairata-rata di atas angka 4,34 (di atas baik). Hal ini ditunjukkan dengan hasil pengolahan data dari5 dimensi dan 20 indikator yang diajukan.Sebagianbesarrespondenmenjawab sangat setuju dan setuju. Darihasilpengolahan data penelitian, responden mempunyai harapan yang lebih tinggidari persepsi atas pelayanan yang diberikan oleh Kantor B2TKS - BPPT. Hal inidibuktikandari skor rata-rata nilai harapan ialah 4,49>4,34. Berdasarkanhasilpenelitian, makakualitaspelayanan yang diberikan oleh B2TKS BPPTsudahdinilaiberjalanpadaharapanpelanggan
\end{abstract}

Kata Kunci : Customer Satisfaction, tangibles, empathy, reliability, assurance, responsiveness dan Pelayanan Jasa Teknologi.

\section{ABSTRACT}

Customer Satisfaction is a very interesting thing to be appointed by a Government Agency such as B2TKS - BPPT, in an effort to win competition from other agencies. The purpose of this study is how customer perceptions of service and service quality provided B2TKS - BPPT has met customer expectations. The method used in this study is a quantitative approach which is then supported by approaches and qualitative data. In this study a questionnaire was used which was determined and designed in the form of questions of Customer Perception and Expectation. The dimensions of the question are 5, namely: tangibles, empathy, reliability, assurance and responsiveness. The population of the questionnaire amounted to 112 customer companies and to obtain representative data, 87 companies were sampled.The results showed that the perceptions of respondents who received services provided by the B2TKS - BPPT Office were rated on average above 4.34 (above is good). This is indicated by the results of processing data from 5 dimensions and 20 indicators proposed. Most respondents answered strongly agree and agreed. From the results of processing research data, respondents have higher expectations of perceptions of services provided by the B2TKS - BPPT Office. This is evidenced by the average score of the expected value is $4.49>4.34$. Based on the results of the study, the quality of services provided by B2TKS - BPPT has been assessed as running on customer expectations

\section{Keywords: Customer Satisfaction,tangibles,empathy,reliability,assurance, responsiveness and}

\section{TechnologyServices.}




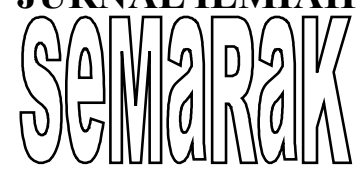

BAB I

\section{PENDAHULUAN}

\subsection{Latar Belakang Masalah}

Sejalan dengan semakin meningkatnya tingkat pendidikan dan kemajuan ilmu pengetahuan dan teknologi serta semakin mudahnya informasi di dapat, maka kebutuhan dan tuntutan masyarakat tentang pelayanan jasa tampak semakin meningkat pula. Perubahan perilaku masyarakat terhadap pelayanan jasa tidak saja menginginkan kecepatan pelayanan tetapi juga menginginkan kepuasan terhadap lingkungan kantor, kebersihan, kenyamanan keramahan, perhatian dan sebagainya.

Secara umum yang dimaksud dengan pelayanan yang bermutu adalah pelayanan yang dapat memuaskan setiap pemakai jasa pelayanan sesuai dengan tingkat kepuasan rata-rata penduduk, serta penyelenggaraannya sesuai dengan kode etik dan standar pelayanan profesi yang telah ditetapkan.

Paradigma baru yang berkembang dalam manajemen untuk menghadapi lingkungan global adalah customer value, continous improvement dan organizational system, yaitu bahwa organisasi harus senantiasa mengadakan perbaikan-perbaikan yang berfokus kepada kepentingan konsumen.

Untuk memenuhi kebutuhan dan tuntutan tersebut, tidak ada upaya lain yang dapat dilakukan kecuali menyelenggarakan pelayanan jasa - dalam hal ini pelayanan jasa teknologi dengan sebaikbaiknya. Kondisi Pelayanan Jasa Teknologi di B2TKS - BPPT saat ini secara umum masih belum memuaskan semua pelanggan, karena keterbatasan pegawai, baik dari segi kuantitas maupun kualitasnya.

\subsection{IdentifikasidanPerumusanMasalah}

Berkaitan dengan Kepuasan pelanggan (customer satisfaction) yang perlu mendapatkan perhatian khusus, sebagai berikut :

Iklim organisasi umumnya kurang kondusif, dimana perilaku yang ditimbulkan dari persepsi pelanggan terhadap gambaran kualitas lingkungan organisasi kurang memperhatikan kebutuhan pelanggan.

$>$ Kepuasan pelanggan, dimana para pelanggan belum puas terhadap pelayanan jasa teknologi yang telah diberikan oleh organisasi, ini disebabkan karena keterbatasan pegawai, baik dari segi kuantitas maupun kualitasnya.

$>$ Persaingan yang sedemikian ketatnya dalam bidang pelayanan jasa teknologi, yang pada dekade terakhir ini, karena banyak pihak instansi pemerintah maupun swasta sebagai pesaing dalam bidang pekerjaan ini dengan harga layanan yang lebih kompetitif dan hasil yang lebih baik

Dari indentifikasi masalah tersebut diatas, maka perumusanmasalahnya adalah sbb :

Masalah kepuasan pelanggan merupakan hal penting dari setiap proses pelayanan jasa teknologi di B2TKS - BPPT, karena kepuasan pelanggan merupakan salah satu indikator bagi mutu pelayanan jasa teknologi.

$>$ Dapat teridentifikasi mengenai mutu pelayanan yang dapat memuaskan pelanggan dan pelayanan yang tidak memuaskan pelanggan, sehingga pihak B2TKS bisa mengoreksi terhadap sebabsebab ketidak puasan pelanggan akan mutu pelayanan yang telah diberikan instansi ini.

$>$ Sejauh ini penelitian kepuasan pelanggan yang telah dilakukan oleh B2TKS - BPPT adalah dengan menyebar angket kuesioner berisi kritik dan saran dengan menyediakan kotak saran. Dengan menggunakan metode servqual, dilakukan pengukuran terhadap lima dimensi kualitas pelayanan, yaitu : tangible, reliability, responsiveness, assurance dan empathy yang dilakukan dua kali pertanyaan, yaitu harapan dan persepsi pelanggan, sehingga akan mendapatkan nilai servqual yang merupakan gap-score dari hasil perhitungan skor persepsi dikurangi skor harapan.

\subsection{Tujuan Penelitian}

Tujuan penelitian ini juga berupaya mencari tahu tentang hal-hal berikutini:

1. Memahamipersepsi

penggunalayananjasaterhadap pelayanan yang ada diB2TKS-BPPT

2. Memahami kualitas pelayanan yang diberikan B2TKS-BPPT apakah telah memenuhi harapan pelanggan. 


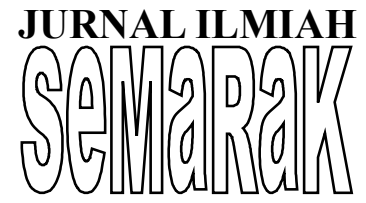

a. Tujuan Umum

Diperoleh informasi mengenai tingkat kepuasan pelanggan terhadap seluruh proses layanan jasa teknologi B2TKS - BPPT dalam beberapa aspek mutu pelayanan

\section{b. Tujuan Khusus}

1) Diperoleh informasi mengenai hubungan kepuasan responden terhadap aspek dimensi Metode Servqual.

2) Diperoleh informasi mengenai aspek dimensi Metode Servqual yang memberikan pengaruh besar secara signifikan terhadap kepuasan pelanggan

3) Diperoleh informasi mengenai kesenjangan (gapscore) tingkat kepuasan antara jasa yang dipersepsikan dengan yang diharapkan pelanggan dengan alat ukur Metode Servqual.

4) Mengindentifikasikan sebab-sebab ketidakpuasan pelanggan terhadap mutu pelayanan di B2TKS - BPPT yang kemudian dapat dipakai sebagai acuan tindakan koreksi dari pihak manajemen untuk mengadakan perbaikan.

\subsection{Manfaat Penelitian}

1. Bagi B2TKS - BPPT

Memberikan input bagi B2TKS - BPPT terutama pihak manajemen mengenai permasalahan mutu pelayanan jasa teknologi dalam upaya meningkatkan kepuasan pelanggan.

2. Bagi Akademis

Diharapkan dapat mengembangkan khazanah Ilmu Pengetahuan dan Teknologi terutama yang berkaitan dengan pengukuran tingkat kepuasan pelanggan dengan Metode Servqual.

3. Bagi Peneliti

Merupakan pengalaman yang berharga untuk dapat mengembangkan wawasan keilmuan tentang kajian Custmer Satisfaction dengan Metode Servqual.

\subsection{Lingkup Penelitian}

Penelitian ini mempunyai sejumlah batasan-batasan sebagai berikut :

1. Penelitian ini dilakukan di Balai besar Teknologi Kekuatan Struktur - Badan Pengkajian dan Penerapan Teknologi, beralamat di Kawasan Puspiptek Setu, Tangerang Selatan - Banten.
2. Penelitian ini hanya membahas tentang kepuasan pelanggan di B2TKS -BPPT dan berusaha mengindentifiksikan faktor-faktor yang mempengaruhi kepuasan pelanggan.

3. Penelitian ini dilaksanakan dengan memberikan kuesioner bagi para pelanggan, dan telah dilaksanakan dari tanggal 2 Januari sampai dengan 8 Februari 2019.

\subsection{Kerangka Pemikiran}

Dalam penelitian ini, Penulis mengemukakan hubungan antara 2 (dua) variabel, yaitu variabel independen (bebas) dan variabel dependen (terikat), bahwa persepsi dan harapan yang baik dari pelanggan maka pelayanan yang diberikan oleh B2TKS -BPPT telah baik pula. Hubungan antara kedua variabel tersebut dapat dilihat dari bagan berikut:

\begin{tabular}{|c|c|c|}
\hline Indikator & Dimensi & Instrumen Pengukuran \\
\hline \multirow{5}{*}{$\begin{array}{l}\text { Persepsi } \\
\text { dan } \\
\text { Harapan }\end{array}$} & $\begin{array}{l}\text { Berwujud } \\
\text { (Tangible) }\end{array}$ & $\begin{array}{l}>\text { Penampilan Petugas B2TKS -BPPT } \\
>\text { Penampilan Fisik B2TKS -BPPT } \\
>\text { Sarana dan Prasarana }\end{array}$ \\
\hline & $\begin{array}{l}\text { Keterhandalan } \\
\text { (Reliability) }\end{array}$ & $\begin{array}{l}>\text { Kemampuan memberikan informasi } \\
>\text { yang mudah dimengerti } \\
>\text { Penguasaan prosedur layanan } \\
>\text { Kecepatan menyelesaikan masalah } \\
>\text { Kesiapan petugas untuk melayani } \\
>\text { PelangganKecepatan memberikan } \\
\text { pelayanan }\end{array}$ \\
\hline & $\begin{array}{l}\text { Daya Tanggap } \\
\text { (Responsivene } \\
\text { ss) }\end{array}$ & $\begin{aligned} & \text { Kesigapan petugas dalam } \\
& \text { menanggapi masalah dengan cepat } \\
> & \text { Kecepatan proses pemberian layanan } \\
> & \text { Kepastian dan kejelasan dalam } \\
\text { penentuan waktu dan biaya } & \\
> & \begin{array}{l}\text { Menyederhanakan } \\
\text { pengurusan layanan }\end{array}\end{aligned}$ \\
\hline & $\begin{array}{l}\text { Keyakinan } \\
\text { (Assurance) }\end{array}$ & $\begin{array}{l}>\text { Keramahan dan kesopanan petugas } \\
>\text { Memberikan komunikasi yang efektif } \\
\text { Sikap percaya diri petugas } \\
\text { Kemampuan memberikan keyakinan } \\
\text { pada Pelanggan }\end{array}$ \\
\hline & $\begin{array}{l}\text { Empati } \\
\text { (Emphaty) }\end{array}$ & $\begin{array}{l}>\text { Kemudahan untuk memberikan } \\
\text { pelayanan } \\
>\text { Bersikap simpatik dalam } \\
\text { memberikan layanan } \\
>\text { Penanganan masalah yang cepat dan } \\
\text { tepat } \\
>\text { Kemudahan untuk menyediakan } \\
\text { waktu kepada pelanggan }\end{array}$ \\
\hline $\begin{array}{c}\text { Tingkat } \\
\text { Kualitas } \\
\text { Pelayanan }\end{array}$ & & $\begin{array}{l}\text { Tingkat Persepsi (Sangat Puas,Puas, } \\
\text { Cukup, Tidak Puas,Sangat Tidak } \\
\text { Puas), Tingkat Harapan (Sangat } \\
\text { Puas,Puas, Cukup, } \\
\text { Puas,Sangat Tidak Puas) }\end{array}$ \\
\hline
\end{tabular}

Tabel1.1.Model Analisis

Variabel Independen Variabel Dependen 


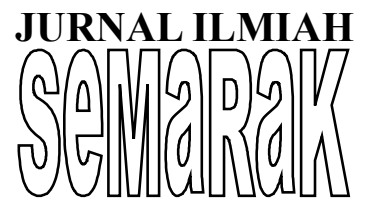

\begin{tabular}{|l|l|}
\hline \multicolumn{1}{|c|}{$\begin{array}{c}\text { Persepsi dan } \\
\text { Harapan }\end{array}$} & \multicolumn{1}{c|}{$\begin{array}{c}\text { PelayananB2TKS } \\
\text {-BPPT }\end{array}$} \\
\hline $\begin{array}{l}\text { - Tangible } \\
\text { (berwujud) }\end{array}$ & $\begin{array}{l}\text { - Tingkat } \\
\text { Kesenjangan }\end{array}$ \\
- Reliability \\
(ketrandalan) \\
$\begin{array}{l}\text { - Responsiveness } \\
\text { (dayatanggap) }\end{array}$ \\
$\begin{array}{l}\text { persepsi dan } \\
\text { - Assurance }\end{array}$ & $\begin{array}{l}\text { jasa } \\
\text { vana diterima }\end{array}$ \\
\hline
\end{tabular}

Hubungan antara variabel secara jelas dapat digambarkan sebagai suatu garis lurus. Variabel independen atau variabel bebas dalam penelitian ini adalah persepsi dan harapan pelanggan yang mempunyai pengaruh terhadap munculnya variabel dependen atau variabel terikat yaitu pelayanan yang diberikan oleh B2TKS -BPPT. Adapun indikator atas pelayanan yang diberikan oleh B2TKS -BPPT adalah tingkat kesenjangan antara persepsi dan harapan atas jasa yang diterima oleh pelanggan atas pelayanan dan tingkat kepuasan yang dirasakan pelanggan oleh atas pelayanan yang prima.

\subsection{Variabel dan Indikator Pengukur}

Berdasarkan lima dimensi kualitas pelayanan tersebut, disusun seperangkat instrumen pengukuran yang terdiri atas lima dimensi kualitas menjadi 20 pertanyaan (kuesioner) yang akan diberikan Pelanggan B2TKS -BPPT. Berikut ini Tabel yang menunjukkan indikator-indikator yang biasanya dipakai pada banyak penelitian

Tabel 1.2 Pengukuran Tingkat KualitasPelayanan
Pelayanan dapat diartikan sebagai setiap usaha yang dilakukan untuk meningkatkan kepuasan para pengguna layanan (whatever enhances customer satisfaction). Pelayanan untukpara pengguna layanan sangat penting sehingga ada ungkapan yang menyatakan bahwa para pengguna layanan adalah raja, para pengguna layanan adalah nomor satu (Daviddow, William, and Uttal, 1989:18). Dinyatakan juga bahwa pelayanan untuk para pengguna layanan merupakan senjata persaingan yang ampuh dalam setiap bidang usaha. Bagian pelayanan jasa,para pengguna layanan merupakan bagian yang paling vital atau mematikan dalam usaha menyingkirkan para pesaing.

\subsubsection{Kepuasan Pelanggan (Customer Satisfaction)}

Kepuasan pelanggan (Customer Satisfaction) adalah suatu keadaan dimana keinginan, harapan dan kebutuhan pelanggan dipenuhi. Suatu pelayanan dinilai memuaskan bila pelayanan tersebut dapat memenuhi kebutuhan dan harapan pelanggan. Pengukuran kepuasan pelanggan merupakan elemen penting dalam menyediakan pelayanan yang lebih baik, lebih efisien dan lebih efektif.

\subsection{Pelayanan Publik}

Pelayanan yang diberikan oleh pemerintah sering disebut pelayanan umum atau pelayanan publik, yaitu pelayanan yang disediakan oleh pemerintah karena masyarakat pada umumnya tidak dapat memenuhi sendiri kebutuhannya kecuali secara kolektif. Pemenuhankebutuhanmasyarakattersebut, dilakukandengantujuantercapainyakesejahteraansosi al yang adil dan merata.

\section{BAB III}

METODOLOGI PENELITIAN

3.1 MetodePenelitian

3.1.1 ObjekPenelitian

\subsection{Definisi Pelayanan}

\subsubsection{Konsep Pelayanan}




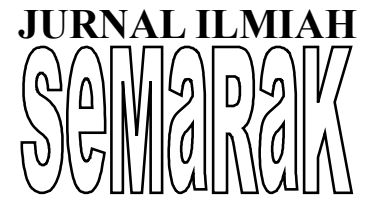

Tujuan penelitian ini adalah untuk mengkaji tingkat persepsi dan harapan pelanggan terhadap pelayanan yang diberikan oleh B2TKS -BPPT, sebagai obyek penelitan ini adalah kualitas pelayanan yang diberikan oleh B2TKS -BPPT.

\subsubsection{JenisPenelitian}

Penelitian yang digunakan untuk menganalisis adalah studi yang menggambarkan keadaan atau kenyataan yang ada, kejadian-kejadian atau kegiatan-kegiatan tentang suatua spek lingkungan sosial, termasuk manusia didalamnya, yang berlangsung sebagai peristiwa sehari-hari ataupun menurut momen-momen tertentu yang sifatnya temporal atau memusatkan kepada aspekaspek tertentu. Penelitian ini adalah pelaksanaan kegiatan pelayanan yang dilaksanakan di B2TKS BPPT.

\subsection{Populasi dan Sampel}

\section{a. Populasi}

Populasi adalah seluruh pelanggan yang memanfaatkan Pelayanan JasaTeknologi di B2TKS BPPT. Jumlah pelanggan di B2TKS -BPPT ialah 112 perusahaan, yang dalam hal ini semua dianggap populasi dalam penelitian ini.

\section{b. Sampel}

Metode penarikan sampel dilakukan berdasarkan kaidah dasar dari probability sampling melalui tehnik pengambilan sapel secara acak (simple random sampling) untuk semua jenis golongan pelanggan, yaitu dengan mengacu pada pendapat Slovin. Diketahui bahwa anggota populasisebanyak 112pelanggan, dan tingkat kesalahan ditetapkan sebesar 5\% maka jumlah sampel penelitian yang didapatkan adalah :

$$
\begin{aligned}
\mathrm{n} & =\frac{N}{1+\epsilon^{2} \cdot N} \mathrm{n}=\text { Responden } \\
\mathrm{n} & =\frac{112}{1+(0,05)^{2} \cdot 112} \\
\mathrm{n} & =87 \text { responden }
\end{aligned}
$$

\subsection{TehnikPengumpulan Data}

MetodePengumpulan Data

Dalampenelitianini, metodepengumpulan data yang digunakanmeliputi:

a. Penelitian Kepustakaan(LibraryResearch)

Penelitian ini digunakan untuk mengumpulkan data sekunder dan menyusun landasanteori yang digunakan sebagai dasar permasalahan, serta sebagai alat untuk menganalisis pokok permasalahan. Pengumpulan data dengan tehnik ini dilakukan dengan cara mempelajari buku, undang-undang, artikel, peraturan daerah, jurnal, dan dokumen-dokumen lain yang relevan dengan topic penelitian.

b. Penelitian Lapangan(FieldResearch)

Tehnik ini digunakan untuk mengumpulkan data primer, yaitu dengan melakukan penelitian langsung melalui metode angket, dengan cara mengajukan kuesioner. Untuk penentuan ukuran sample dari populasi tersebut dengan menggunakan tehnik sampling yang bersifat nonprobability sampling.

\subsection{Teknik Pengukuran data}

Untuk dapat mengukur kualitas pelayanan yang diberikan oleh B2TKS -BPPT kepada pelanggan, maka dalam penelitian ini digunakan Skala Pengukuran Likert

Dengan skala likert, maka variable akan diukur dan dijabarkan menjadi indicator variabel, yang kemudian indicator tersebut dijadikan sebagai titik tolak untuk menyusun item instrumen yang dapat berupa pertanyaan atau pernyataan yang akan dijawab oleh responden. Setiap item pertanyaan memiliki 5 pilihanjawaban dari tingkat persepsi dan harapan pelanggan diberikan bobot yang disusun berdasarkan Skala Likert, sebagai berikut :
a. Sangat tidak puas, dengan skor 1;
b. Tidakpuas, denganskor 2;
c. Cukuppuas denganskor 3;
d. Puas , denganskor 4;
e. Sangatpuas, denganskor 5;

\subsection{Teknik Pengukuran Servqual}

Untuk menunjang hasil analisis deskriptif, penulis menunjang dengan teori yang ada, yaitu 
$\mathrm{P}-\mathrm{H}=0$ maka Tingkat Pelayanansamadengan yang diharapkanpelanggan

$\mathrm{P}-\mathrm{H}>0$ maka Tingkat Pelayanansangat

memuaskanpelanggan

$\mathrm{P}-\mathrm{H}<0$ maka Tingkat Pelayanankurang

Memuaskanpelanggan

analisis ServQual yang dikembangkan Parasuraman, Berry dan Zeitham. Dengan demikian, pendekatannya adalah pendekatan kuantitatif, dimana pada pendekatan tersebut menerapkan metode deduktif dalamarti peneliti sebelum turun kelapangan telah mempunyaiteori, konsep dan variabel.

Teori ServQual yakni"exceeding what customers expect from the service" (Parasuraman, Zeithaml and Berry, :1990) mempunyai alat bantu instrument untuk dapat mengukur tingkat kualitas pelayanan, yaitu dengan mengacu pada lima dimensi kualitas pelayanan, yaitu tampilan fisik(tangibles),keterandalan(reliability),ketanggapa $\mathrm{n}$ (responsiveness), jaminan(assurance) dan empati(emphaty). Pada setiap dimensi diberikan indicator untuk mengetahui gambaran mengenai kualitas tingkat kualitas pelayanan, lalu selisih skor persepsi dengan skor harapan pelanggan menggambarkan kualitas pelayanan yang diterima oleh Pelanggan. Menurut Parasuraman, Berry dan Zeitham,

untukmengukurKualitasPelayanandapatdigunakanru mus di bawahini:

Skor ServQual $=$ Total Skor Persepsi - Total Skor Harapan
$K P$
$P$
$H$

Keterangan:

$\mathrm{KP}=$ KualitasPelayanan

$$
\begin{array}{ll}
\mathrm{P} & =\text { SkorPersepsiPelanggan } \\
\mathrm{H} & =\text { SkorHarapanPelanggan }
\end{array}
$$

Bilanilai:

Untukmengetahuiskor

rata-rata ataubobotnilaitengahdigunakanrumussebagaiberikut:

$\mathrm{Y}=(1 \mathrm{XR} 1)+(2 \mathrm{X} \mathrm{R} 2)+(3 \mathrm{XR} 3)+(4 \mathrm{X} \mathrm{R} 4)$

$+(5$ X R5)

$(\mathrm{R} 1+\mathrm{R} 2+\mathrm{R} 3+\mathrm{R} 4+\mathrm{R} 5)$

Keterangan :

$\mathrm{Y}=$ nilai skor rata-rata

Angka $1 \mathrm{~s} / \mathrm{d} 5=$ nilai skor

R1 s/d R5= jumlah responden yg memilih skor 1-5

$(\mathrm{R} 1+\mathrm{R} 2+\mathrm{R} 3+\mathrm{R} 4+\mathrm{R} 5)=$ total responden keseluruhan

\subsection{Validitas dan Reliabilitas Instrumen}

Hasil penelitian dikatakan valid bila terdapat kesamaan antara data yang terkumpul dengan data yang sesungguhnya terjadi pada obyek yang diteliti. Kalau dalam obyek berwarna hijau, sedangkan data yang terkumpul memberikan data berwarna putih, maka hasil penelitian menjadi tidak valid. Sedangkan hasil penelitian yang reliabel, bila terdapat kesamaan data dalam waktu yang berbeda. Kalau dalam obyek kemarin berwarna hijau, maka sekarang dan besok tetap berwarna hijau..

Jadi instrumen yang valid dan reliabel, merupakan syarat mutlak untuk mendapatkan hasil penelitian yang valid dan reliabel. Hal ini tidak berarti bahwa dengan menggunakan instrumen yang telah teruji validitas dan reliabilitasnya, serta merta penelitiannya menjadi valid dan reliabel. Reliabilitas instrumen merupakan syarat untuk pengujian 


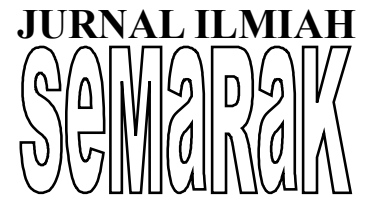

validitas instrumen. Oleh karena itu, walaupun instrumen yang valid pasti reliabel, tetapi pengujian reliabilitas instrumen perlu dilakukan

$$
\mathrm{r} 1=\underline{2 \times r 2}
$$

$1+\mathrm{rk}$

Dengan :

r1 = Nilai Reliabilitas Spearman Brown

$\mathrm{rk}=$ Koefisien korelasi antar kelompok variabel

\section{BAB IV}

\section{HASIL PENELITIAN DAN PEMBAHASAN}

\subsection{Deskripsi Data Hasil Penelitian}

Dengan mengacu pada pendapat Slovin, diketahui bahwa anggota populasisebanyak 112pelanggan, dan tingkat kesalahan ditetapkan sebesar 5\% maka jumlah sampel penelitian yang didapatkan adalah :

$$
\mathrm{n}=\frac{N}{1+\epsilon^{2} . N} \mathrm{n}=\text { Responden }
$$

$\mathrm{n}=\frac{112}{1+(0,05)^{2} .112}$

$\mathrm{N}=$ Populasi (112 Pelanggan)

$\mathrm{n}=87$ Responden

Variabel-variabel yang akan diukur dalam penelitian ini dikelompokkan menjadi 2 (dua), yaitu variabel bebas dan variabel terikat. Variabel-variabel tersebut dapat dibagi atas tiga bagian, yaitu variabel bebas (X) yang terdiri dari variabel Persepsi Pelanggan $\left(\mathrm{X}_{1}\right)$, Harapan Pelanggan $\left(\mathrm{X}_{2}\right)$ dan variabel terikat yaitu Pelayanan Jasa Teknologi (Y). Pengaruh antara variabel-variabel tersebut secara operasional dapat digambarkan dalam uraian-uraian pembuktian hubungan antar variabel. Dalam penelitian ini, pertanyaan tentang Persepsi Pelanggan $\left(X_{1}\right)$ berjumlah 20 item dan alternatif pilihan nilai 1-5, dengan jumlah responden 87. Pertanyaan Harapan Pelanggan $\left(\mathrm{X}_{2}\right)$ berjumlah 20 dengan alternatif pilihan dengan nilai 1-5, dengan jumlah responden 87. Sedangkan pertanyaan Pelayanan Jasa Teknologi (Y) berjumlah 20 dengan alternatif pilihan $1-5$ dengan jumlah responden 87 yang kemudian dimodifikasi menjadi dengan alternatif pilihan dengan nilai 1- 5 seperti dibawah ini.

\subsection{Analisa Data}

\subsubsection{Analisa Data Persepsi Pelanggan}

Dari perhitungan hasil penelitian diperoleh nilai sampel Persepsi Pelanggan sebanyak 7.553 (lampiran 1). Dengan menganalisis data seperti di bawah ini, dari aspek penilaian sampel diperoleh variabel Persepsi Pelanggan yang ditampilkan oleh responden ialah 7.553: $8.700=88,81 \%$ atau nilai 88 dari kriteria yang diharapkan (skor tertinggi ialah 100). Dengan demikian posisi nilai aspek Persepsi Pelanggan responden berada pada posisi 'sangat tinggi'.

\section{Tabel 4.1. Indikator Persepsi Pelanggan}

\begin{tabular}{|l|l|l|l|}
\hline No & Indikator & $\%$ & Kategori \\
\hline 1. & $\begin{array}{l}\text { Kondisi dan tata } \\
\text { ruang kantor } \\
\text { menyenangkan }\end{array}$ & 0.76 & $\begin{array}{l}\text { Sangat } \\
\text { Baik }\end{array}$ \\
\hline 2. & $\begin{array}{l}\text { Jumlah, jenis dan } \\
\text { kondisi peralatan } \\
\text { kerja }\end{array}$ & 0.78 & $\begin{array}{l}\text { Sangat } \\
\text { Baik }\end{array}$ \\
\hline 3. & $\begin{array}{l}\text { Ruang kantor } \\
\text { Indah, nyaman } \\
\text { dan bersih }\end{array}$ & 0.80 & $\begin{array}{l}\text { Sangat } \\
\text { Baik }\end{array}$ \\
\hline 4. & $\begin{array}{l}\text { Tersedianya } \\
\text { berbagai fasilitas } \\
\text { dan kotak saran } \\
\text { bagi pelanggan }\end{array}$ & 0.77 & Baik \\
\hline 5 & $\begin{array}{l}\text { Proses pelayanan } \\
\text { cepat dan tepat }\end{array}$ & 0.77 & Baik \\
\hline 6. & $\begin{array}{l}\text { Prosedur } \\
\text { pelayanan tidak }\end{array}$ & 0.77 & Baik \\
\hline
\end{tabular}


Jurnal Semarak,Vol. 2,No.2, Juni 2019, Hal (124- 143)

@Prodi Manajemen Fakultas Ekonomi Universitas Pamulang

\begin{tabular}{|c|c|c|c|}
\hline & berbelit-belit & & \\
\hline 7. & $\begin{array}{l}\text { Rincian biaya } \\
\text { pelayanan cukup } \\
\text { jelas }\end{array}$ & 0.77 & Baik \\
\hline 8. & $\begin{array}{l}\text { Aparat } \\
\text { memahami } \\
\text { aturan pelayanan } \\
\text { yang baik }\end{array}$ & 0.75 & Baik \\
\hline 9. & $\begin{array}{l}\text { Petugas } \\
\text { memberikan } \\
\text { Pelayanan yang } \\
\text { berkualitas pada } \\
\text { pelanggan }\end{array}$ & 0.75 & Baik \\
\hline $\begin{array}{c}10 \\
.\end{array}$ & $\begin{array}{l}\text { Petugas cepat } \\
\text { tanggap terhadap } \\
\text { segala masalah } \\
\text { yang } \\
\text { disampaikan } \\
\text { langsung }\end{array}$ & 0.77 & Baik \\
\hline 11. & $\begin{array}{l}\text { Petugas cepat } \\
\text { tanggap terhadap } \\
\text { keluhan } \\
\text { pelanggan yang } \\
\text { disampaikan } \\
\text { pada kotak saran }\end{array}$ & 0.70 & Baik \\
\hline $\begin{array}{l}12 \\
.\end{array}$ & $\begin{array}{lr}\text { Petugas } & \text { segera } \\
\text { mengubah } & \\
\text { pelayanan } & \text { yang } \\
\text { buruk } & \text { yang } \\
\text { dikritisi } & \text { oleh } \\
\text { pelanggan } & \end{array}$ & 0.67 & Baik \\
\hline $\begin{array}{l}13 \\
.\end{array}$ & $\begin{array}{l}\text { Keramahan } \\
\text { petugas dalam } \\
\text { pelayanan } \\
\text { terhadap } \\
\text { pelanggan }\end{array}$ & 0.73 & Baik \\
\hline 14 & $\begin{array}{l}\text { Kesopanan } \\
\text { petugas dalam } \\
\text { pelayanan } \\
\text { terhadap } \\
\text { pelanggan }\end{array}$ & 0.74 & Baik \\
\hline
\end{tabular}

\begin{tabular}{|l|l|l|l|}
\hline 15 & $\begin{array}{l}\text { Terlihat } \\
\text { keharmonisan } \\
\text { hubungan antar } \\
\text { pegawai }\end{array}$ & 0.76 & Baik \\
\hline 16 & $\begin{array}{l}\text { Ketepatan dan } \\
\text { ketegasan } \\
\text { aparatur dalam } \\
\text { menerapkan } \\
\text { peraturan }\end{array}$ & 0.76 & Baik \\
\hline 17 & $\begin{array}{l}\text { Kemauan petugas } \\
\text { untuk } \\
\text { mendengarkan } \\
\text { keluhan } \\
\text { pelanggan }\end{array}$ & $\begin{array}{l}\text { Baik } \\
.\end{array}$ & $\begin{array}{l}\text { Kemauan petugas } \\
\text { untuk mencatat } \\
\text { semua keluhan }\end{array}$ \\
\hline 19 & $\begin{array}{l}\text { Keinginan yang } \\
\text { kuat dari petugas } \\
\text { untuk 0.77 } \\
\text { mensosilalisikan } \\
\text { pelayanan pada } \\
\text { pelanggan }\end{array}$ & Baik \\
\hline 20 & $\begin{array}{l}\text { Terlihat adanya } \\
\text { Kemauan } \\
\text { betugas untuk } \\
\text { baik daha } \\
\text { pelayanan }\end{array}$ & Baik \\
\hline
\end{tabular}

Sumber: Diolah dari lampiran

\subsubsection{Analisis Data Harapan Pelanggan}

Dari data lampiran jumlah skor yang diperoleh atas perhitungan hasil penelitian Harapan Pelanggan berjumlah 7.902. Jumlah skor dengan nilai paling tinggi bila semua responden menjawab dengan skor tersebut pada setiap instrumen, maka diperoleh nilai 5 x 20 × $87=8.700$. Jadi dengan menganalisis data Harapan Pelanggan, maka secara keseluruhan performansi Harapan Pelanggan yang ditampilkan oleh para responden ialah: 
Jurnal Semarak,Vol. 2,No.2, Juni 2019, Hal (124- 143)

(a) Prodi Manajemen Fakultas Ekonomi Universitas Pamulang

$7.902: 8.700 \times 100 \%=90,83 \%$ atau nilai 91 dari nilai 100 yang diharapkan. Secara kontinum variabel Harapan Pelanggan pegawai termasuk kategori nilai 'sangat tinggi', yang dapat digambarkan sebagai berikut:

Tabel 4.2. Indikator Harapan Pelanggan

\begin{tabular}{|c|c|c|c|}
\hline No. & Indikator & $\%$ & Kategori \\
\hline 1. & $\begin{array}{l}\text { Ttata ruang } \\
\text { kantor } \\
\text { menyenangkan }\end{array}$ & 0.76 & $\begin{array}{l}\text { Sangat } \\
\text { Baik }\end{array}$ \\
\hline 2. & $\begin{array}{l}\text { Jumlah, jenis dan } \\
\text { kondisi peralatan } \\
\text { kerja }\end{array}$ & 0.78 & $\begin{array}{l}\text { Sangat } \\
\text { Baik }\end{array}$ \\
\hline 3. & $\begin{array}{l}\text { Suasana kantor } \\
\text { (Keindahan, } \\
\text { nyaman dan } \\
\text { bersih) }\end{array}$ & 0.80 & $\begin{array}{l}\text { Sangat } \\
\text { Baik }\end{array}$ \\
\hline 4. & $\begin{array}{l}\text { Tersedianya } \\
\text { berbagai fasilitas } \\
\text { dan kotak saran } \\
\text { bagi pelanggan }\end{array}$ & 0.77 & Baik \\
\hline 5 & $\begin{array}{l}\text { Proses pelayanan } \\
\text { cepat dan tepat }\end{array}$ & 0.77 & Baik \\
\hline 6. & $\begin{array}{l}\text { Prosedur } \\
\text { pelayanan tidak } \\
\text { berbelit-belit }\end{array}$ & 0.77 & Baik \\
\hline 7. & $\begin{array}{lr}\text { Rincian } & \text { biaya } \\
\text { pelayanan } & \text { cukup } \\
\text { jelas } & \end{array}$ & 0.77 & Baik \\
\hline 8. & $\begin{array}{l}\text { Aparat } \\
\text { memahami aturan } \\
\text { pelayanan yang } \\
\text { baik }\end{array}$ & 0.75 & Baik \\
\hline 9. & $\begin{array}{l}\text { Petugas } \\
\text { memberikan } \\
\text { Pelayanan yang } \\
\text { berkualitas pada } \\
\text { pelanggan }\end{array}$ & 0.75 & Baik \\
\hline
\end{tabular}

\begin{tabular}{|c|c|c|c|}
\hline 10. & $\begin{array}{l}\text { Petugas cepat } \\
\text { tanggap terhadap } \\
\text { segala masalah } \\
\text { yang } \\
\text { disampaikan } \\
\text { langsung }\end{array}$ & 0.77 & Baik \\
\hline 11. & $\begin{array}{l}\text { Petugas cepat } \\
\text { tanggap terhadap } \\
\text { keluhan } \\
\text { pelanggan yang } \\
\text { disampaikan pada } \\
\text { kotak saran }\end{array}$ & 0.70 & Baik \\
\hline 12. & $\begin{array}{lr}\text { Petugas } & \text { segera } \\
\text { mengubah } & \\
\text { pelayanan } & \text { yang } \\
\text { buruk } & \text { yang } \\
\text { dikritisi } & \text { oleh } \\
\text { pelanggan } & \end{array}$ & 0.67 & Baik \\
\hline 13. & $\begin{array}{l}\text { Keramahan } \\
\text { petugas dalam } \\
\text { pelayanan } \\
\text { terhadap } \\
\text { pelanggan }\end{array}$ & 0.73 & Baik \\
\hline 14. & $\begin{array}{l}\text { Kesopanan } \\
\text { petugas dalam } \\
\text { pelayanan } \\
\text { terhadap } \\
\text { pelanggan }\end{array}$ & 0.74 & Baik \\
\hline 15. & $\begin{array}{l}\text { Terlihat } \\
\text { keharmonisan } \\
\text { hubungan antar } \\
\text { pegawai }\end{array}$ & 0.76 & Baik \\
\hline 16. & $\begin{array}{l}\text { Ketepatan dan } \\
\text { ketegasan } \\
\text { aparatur dalam } \\
\text { menerapkan } \\
\text { peraturan }\end{array}$ & 0.76 & Baik \\
\hline 17. & $\begin{array}{l}\text { Kemauan petugas } \\
\text { untuk } \\
\text { mendengarkan } \\
\text { keluhan }\end{array}$ & 0.75 & Baik \\
\hline
\end{tabular}




\begin{tabular}{|l|l|l|l|}
\hline JURNAL ILMIAH & \multicolumn{3}{|c|}{$\begin{array}{l}\text { P-ISSN 2615 } \\
\text { @ernal Semara Manajem }\end{array}$} \\
\hline 18. & $\begin{array}{l}\text { Kemauan petugas } \\
\text { untuk mencatat } \\
\text { semua keluhan }\end{array}$ & 0.77 & Baik \\
\hline 19. & $\begin{array}{l}\text { Keinginan yang } \\
\text { kuat dari petugas } \\
\text { untuk } \\
\text { mensosilalisikan } \\
\text { pelayanan pada } \\
\text { pelanggan }\end{array}$ & $\begin{array}{l}\text { Baik } \\
\text { Kelangan } \\
\text { untuk berusaha } \\
\text { lebih baik dalam } \\
\text { pelayanan }\end{array}$ & Baik \\
\hline 20. & \begin{tabular}{l} 
Terlihat adanya \\
\hline
\end{tabular} & 0.77 & \\
\hline
\end{tabular}

Sumber: Diolah dari lampiran

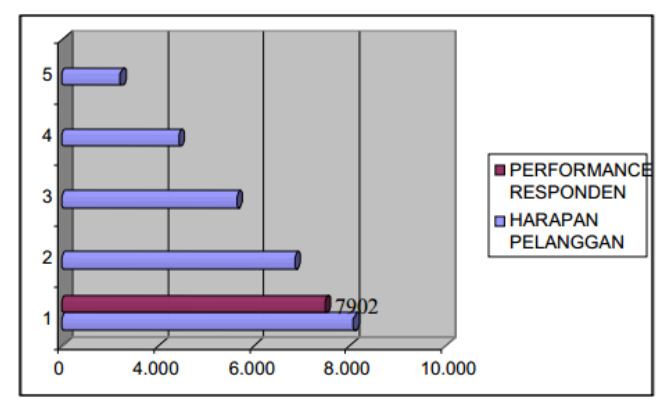

Nilai Harapan Pelanggan tersebut merupakan gabungan atas total dari indikatorindikator Harapan Pelanggan yang terdiri atas terdiri dari 20 indikator. Untuk memperoleh gambaran Harapan Pelanggan dari masing-masing indikator adalah sebagai berikut

\subsubsection{Analisis SkorPersepsi Pelanggan}

Dari data kuesioner responden jumlah skor yang diperoleh atas perhitungan hasil penelitian Persepsi Pelanggan berjumlah 86,82 . Bila nilai ini dibagi atas 20 indikator yang merupakan 20 pernyataan penelitian dan jawaban dari responden, maka diperoleh angka rata-rata nilai Persepsi responden ialah 4,34. Skore 4,34 itu mendekati angka 5, yang berarti Persepsi pelanggan begitu besar terhadap pelayanan yang diberikan kantorB2TKS - BPPT. Lihat tabel dibawah :

\section{Tabel 4.3 Indikator Persepsi Pelanggan}

\begin{tabular}{|c|c|c|}
\hline No. & Indikator & Skor \\
\hline 1. & Kondisi dan tata ruang kantor & 4,34 \\
\hline 2. & $\begin{array}{l}\text { Jumlah, jenis dan kondisi } \\
\text { peralatan kerja }\end{array}$ & 4,48 \\
\hline 3. & $\begin{array}{l}\text { Ruang kantor Indah, nyaman } \\
\text { dan bersih }\end{array}$ & 4,59 \\
\hline 4. & $\begin{array}{l}\text { Tersedianya berbagai fasilitas } \\
\text { dan kotak saran bagi } \\
\text { pelanggan }\end{array}$ & 4,43 \\
\hline 5 & $\begin{array}{l}\text { Proses pelayanan cepat dan } \\
\text { tepat }\end{array}$ & 4,41 \\
\hline 6. & $\begin{array}{l}\text { Prosedur pelayanan tidak } \\
\text { berbelit-belit }\end{array}$ & 4,45 \\
\hline 7. & $\begin{array}{l}\text { Rincian biaya pelayanan } \\
\text { cukup jelas }\end{array}$ & 4,40 \\
\hline 8. & $\begin{array}{l}\text { Aparat memahami aturan } \\
\text { pelayanan yang baik }\end{array}$ & 4,30 \\
\hline 9. & $\begin{array}{lr}\text { Petugas memberikan } \\
\text { Pelayanan yang berkualitas } \\
\text { pada pelanggan }\end{array}$ & 4,33 \\
\hline 10. & $\begin{array}{l}\text { Petugas cepat tanggap } \\
\text { terhadap segala masalah yang } \\
\text { disampaikan langsung }\end{array}$ & 4,43 \\
\hline 11. & $\begin{array}{l}\text { Petugas cepat } \quad \text { tanggap } \\
\text { terhadap keluhan pelanggan } \\
\text { disampaikan di kotak saran }\end{array}$ & 4,05 \\
\hline 12. & $\begin{array}{l}\text { Petugas segera mengubah } \\
\text { pelayanan yang buruk yang } \\
\text { dikritisi oleh pelanggan }\end{array}$ & 3,87 \\
\hline 13. & $\begin{array}{l}\text { Keramahan petugas dalam } \\
\text { pelayanan terhadap pelanggan }\end{array}$ & 4,20 \\
\hline 14. & $\begin{array}{l}\text { Kesopanan petugas dalam } \\
\text { pelayanan terhadap pelanggan }\end{array}$ & 4,25 \\
\hline
\end{tabular}


Jurnal Semarak,Vol. 2,No.2, Juni 2019, Hal (124- 143)

(a) Prodi Manajemen Fakultas Ekonomi Universitas Pamulang

\begin{tabular}{|c|c|c|}
\hline 15. & $\begin{array}{l}\text { Keharmonisan hubungan antar } \\
\text { pegawai }\end{array}$ & 4,38 \\
\hline 16. & $\begin{array}{l}\text { Ketepatan dan } \begin{array}{l}\text { ketegasan } \\
\text { aparatur dalam menerapkan } \\
\text { peraturan }\end{array}\end{array}$ & 4,33 \\
\hline 17. & $\begin{array}{lr}\text { Kemauan petugas } & \text { untuk } \\
\text { mendengarkan } & \text { keluhan } \\
\text { pelanggan } & \end{array}$ & 4,36 \\
\hline 18. & $\begin{array}{l}\text { Kemauan petugas untuk } \\
\text { mencatat semua keluhan }\end{array}$ & 4,44 \\
\hline 19. & $\begin{array}{lr}\text { Keinginan yang } & \text { kuat dari } \\
\text { petugas } & \text { untuk } \\
\text { mensosilalisikan } & \text { pelayanan } \\
\text { pada pelanggan } & \end{array}$ & 4,37 \\
\hline 20. & $\begin{array}{l}\text { Terlihat adanya Kemauan } \\
\text { Petugas untuk berusaha lebih } \\
\text { baik dalam pelayanan }\end{array}$ & 4,41 \\
\hline
\end{tabular}

Sumber: Diolah dari lampiran

\subsubsection{Analisis Skor Harapan Pelanggan}

Dari data kuesioner responden jumlah skor yang diperoleh atas perhitungan hasil penelitian Harapan Pelanggan berjumlah 89,66, lebih tinggi dari persepsi pelanggan. Bila nilai ini dibagi atas 20 indikator yang merupakan 20 pernyataan penelitian dan jawaban dari responden, maka diperoleh angka rata-rata nilai harapan responden ialah 4,48 . Skore 4,48 itu mendekati angka 5, yang berarti harapan pelanggan begitu besar terhadap pelayanan yang diberikan kantorB2TKS - BPPT. Secara lebih rinci skor per item nilai per pertanyaan dari kuesioner adalahsebagaiberikut :Tabel 4.4. Indikator Harapan Pelanggan

\begin{tabular}{|l|l|l|}
\hline No. & Indikator & $\mathbf{\%}$ \\
\hline 1. & Kondisi dan tata ruang kantor & 4,47 \\
\hline 2. & $\begin{array}{l}\text { Jumlah, jenis dan kondisi } \\
\text { peralatan kerja }\end{array}$ & 4,78 \\
\hline 3. & $\begin{array}{l}\text { Ruang kantor Indah, nyaman dan } \\
\text { bersih }\end{array}$ & 4,74 \\
\hline
\end{tabular}

\begin{tabular}{|c|c|c|}
\hline 4. & $\begin{array}{l}\text { Tersedianya berbagai fasilitas dan } \\
\text { kotak saran bagi pelanggan }\end{array}$ & 3,79 \\
\hline 5 & Proses pelayanan cepat dan tepat & 4,39 \\
\hline 6. & $\begin{array}{l}\text { Prosedur pelayanan tidak } \\
\text { berbelit-belit }\end{array}$ & 4,67 \\
\hline 7. & $\begin{array}{l}\text { Rincian biaya pelayanan cukup } \\
\text { jelas }\end{array}$ & 4,41 \\
\hline 8. & $\begin{array}{l}\text { Pemahaman aturan pelayanan } \\
\text { yang baik }\end{array}$ & 3,87 \\
\hline 9. & $\begin{array}{l}\text { Petugas memberikan Pelayanan } \\
\text { yang berkualitas pada pelanggan }\end{array}$ & 4,67 \\
\hline 10. & $\begin{array}{l}\text { Petugas cepat tanggap terhadap } \\
\text { segala masalah yang disampaikan } \\
\text { langsung }\end{array}$ & 4,66 \\
\hline 11. & $\begin{array}{l}\text { Petugas cepat tanggap terhadap } \\
\text { keluhan pelanggan disampaikan } \\
\text { di kotak saran }\end{array}$ & 4,75 \\
\hline 12. & $\begin{array}{l}\text { Petugas segera mengubah } \\
\text { pelayanan yang buruk yang } \\
\text { dikritisi oleh pelanggan }\end{array}$ & 3,68 \\
\hline 13. & $\begin{array}{l}\text { Keramahan petugas dalam } \\
\text { pelayanan terhadap pelanggan }\end{array}$ & 4,68 \\
\hline 14. & $\begin{array}{l}\text { Kesopanan petugas dalam } \\
\text { pelayanan terhadap pelanggan }\end{array}$ & 4,68 \\
\hline 15. & $\begin{array}{l}\text { Terlihat keharmonisan hubungan } \\
\text { antar pegawai }\end{array}$ & 4,68 \\
\hline 16. & $\begin{array}{l}\text { Ketepatan dan ketegasan aparatur } \\
\text { dalam menerapkan peraturan }\end{array}$ & 4,79 \\
\hline 17. & $\begin{array}{l}\text { Kemauan petugas untuk } \\
\text { mendengarkan keluhan pelanggan }\end{array}$ & 4,78 \\
\hline 18. & $\begin{array}{l}\text { Kemauan petugas untuk mencatat } \\
\text { semua keluhan }\end{array}$ & 4,16 \\
\hline 19. & $\begin{array}{l}\text { Keinginan yang kuat dari petugas } \\
\text { untuk mensosilalisikan pelayanan } \\
\text { pada pelanggan }\end{array}$ & 4,87 \\
\hline 20. & $\begin{array}{l}\text { Terlihat adanya Kemauan Petugas } \\
\text { untuk berusaha lebih baik dalam }\end{array}$ & 4,14 \\
\hline
\end{tabular}




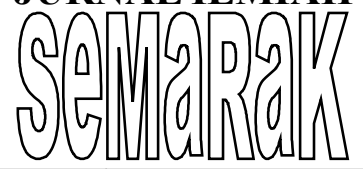

\begin{tabular}{|l|l|l|}
\hline & & \\
\hline Sumber: Delayanan & \\
\hline
\end{tabular}

\subsubsection{Perbandingan Skor Data Persepsi dan} Harapan Pelanggan

Pada setiap dimensi diberikan indikator untuk mengetahui gambaran mengenai kualitas tingkat kualitas pelayanan, lalu selisih skor persepsi dengan skor harapan pelanggan menggambarkan kualitas pelayanan yang diterima oleh Pelanggan. Menurut Parasuraman, Berry dan Zeitham, untuk mengukur Kualitas Pelayanan dapat digunakan rumus di bawah ini :

Skor ServQual $=$ Total Skor Persepsi - Total Skor Harapan

$\mathrm{KP}=\mathrm{P}-\frac{\mathrm{H}}{\mathrm{H}}$

Keterangan:

$$
\begin{array}{ll}
\mathrm{KP} & =\text { Kualitas Pelayanan } \\
\mathrm{P} & =\text { Skor Persepsi Pelanggan } \\
\mathrm{H} & =\text { Skor Harapan Pelanggan }
\end{array}
$$

Untuk mengetahui skor rata-rata atau bobot nilai tengah digunakan rumus sebagai berikut:

$$
\begin{aligned}
& Y=(1 \text { X R1) + (2 X R2) + (3 X R3) } \\
& +(4 \text { X R4) + (5 X R5)(R1 + R2 + R3 } \\
& + \text { R4 + R5) }
\end{aligned}
$$

Dari hasil skoring data maka diperoleh nilai untuk persepsi pelanggan ialah 7.553, sedangkan skor untuk harapan pelanggan ialah 7.902. Dari hasil ini, bila diperbandingkan dengan penghitungan rumus di atas, maka diperoleh nilai persepsi pelanggan lebih kecil dibandingkan nilai harapan pelanggan, atau P$\mathrm{H}<0$. Arti tersebut dapat diterjemahkan dalam tabel berikut, yaitu:Bila nilai :

$\mathrm{P}-\mathrm{H}=0$ maka Tingkat Pelayanan sama dengan

\begin{tabular}{|c|c|c|c|c|}
\hline \multirow[b]{2}{*}{ No } & \multirow[b]{2}{*}{ Indikator } & \multicolumn{2}{|l|}{ Skor } & \multirow[b]{2}{*}{ Gap } \\
\hline & & Persepsi & Harapan & \\
\hline 1 & $\begin{array}{l}\text { Kondisi dan } \\
\text { tata ruang } \\
\text { kantor } \\
\text { menyenangk } \\
\text { an }\end{array}$ & 4,34 & 4.47 & $-0,13$ \\
\hline 2 & $\begin{array}{l}\text { Jumlah, jenis } \\
\text { dan kondisi } \\
\text { peralatan } \\
\text { kerja }\end{array}$ & 4,48 & 4.78 & $-0,30$ \\
\hline 3 & $\begin{array}{l}\text { Ruang kantor } \\
\text { Indah, } \\
\text { nyaman dan } \\
\text { bersih }\end{array}$ & 4.59 & 4.74 & $-0,15$ \\
\hline 4 & $\begin{array}{l}\text { Tersedianya } \\
\text { berbagai } \\
\text { fasilitas dan } \\
\text { kotak saran } \\
\text { bagi } \\
\text { pelanggan }\end{array}$ & 4,43 & 3,79 & 0,64 \\
\hline & Rata-Rata & 4,46 & 4.45 & 0.06 \\
\hline
\end{tabular}
yang

diharapkan pelanggan

$\mathrm{P}-\mathrm{H}>0$ maka Tingkat Pelayanan sangat

memuaskan
pelanggan
$\mathrm{P}-\mathrm{H}<0$ maka Tingkat Pelayanan kurang
memuaskan
pelanggan

Skor antara persepsi pelanggan bila

dibandingkan dengan harapan pelanggan tidak begitu jauh, terpaut sekitar 349 poin. Berlaku untuk 87 responden (pelanggan yang di evaluasi). Dengan demikian dapat disimpulkan bahwa tingkat pelayanan masih di bawah harapan pelanggan. 


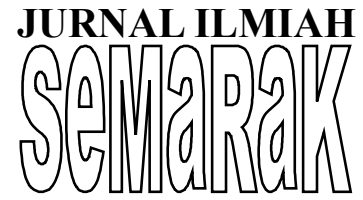

Berikut ini adalah hasil kesenjangan dari tiap indikator atas pelayanan yang diberikan oleh Pelayanan Jasa Teknologi di B2TKS - BPPT yang didapat dari pengolahan data hasil penelitian penulis.

\section{Dimensi Tangibles}

Tabel 4.5. Kesenjangan antara Persepsi dan Harapan Dimensi Tangibles

Sumber: Hasil Pengolahan Data

Dari hasil yang didapat, seperti yang tampak pada diagram di atas dapat dikatakan bahwa seluruh indikator yang ada dalam dimensi tangibles ada yang sesuai dan ada yang tidak ada yang sesuai dengan harapan pelanggan. Gap Kondisi dan tata ruang kantor mencapai $-0,13$, yang menandakan bahwa responden menginginkan Kondisi dan tata ruang kantor yang lebih menyenangkan dibandingkan saat ini.

Indikator jumlah, jenis dan kondisi peralatan kerja mendapatkan respon kuat dari pelanggan agar dilakukannya pembaharuan sesuai perkembangan jaman. Indikator ini menjadi gap yang paling besar dari tiga dimensi harapan respondenj pada dimensi Tangibles yang mencapai nilai $-0,30$. Indikator kenyamanan suasana kantor terdapat gap walau tidak begitu besar yakni -0,15. Hal ini menandakan bahwa Pelanggan menginginkan suasana kantor yang jauh lebih nyaman, indah dibandingkan dengan saat ini. Mengenai indikator kelengkapan fasiltas informasi kantor dan keberadaan kotak saran melebihi harapan dari pelanggan sebesar 0,64.

\section{Dimensi Reliability}

Tabel 4.6. Kesenjangan antara Persepsi dan Harapan Dimensi Reliability

\begin{tabular}{|l|l|l|l|l|}
\hline \multirow{2}{*}{ No } & Indikator & \multicolumn{2}{|l|}{ Skor } & Persepsi \\
\cline { 3 - 4 } 1 & $\begin{array}{l}\text { Proses } \\
\text { pelayanan } \\
\text { cepat dan } \\
\text { tepat }\end{array}$ & 4,41 & 4,39 & \\
\hline & & 0,02 \\
\hline
\end{tabular}

\begin{tabular}{|l|l|l|l|l|}
\hline 2 & $\begin{array}{l}\text { Prosedur } \\
\text { pelayanan } \\
\text { tidak } \\
\text { berbelit-belit }\end{array}$ & 4,45 & 4,67 & $-0,22$ \\
\hline 3 & $\begin{array}{l}\text { Rincian } \\
\text { biaya } \\
\text { pelayanan } \\
\text { cukup jelas }\end{array}$ & 4,40 & 4,41 & $-0,01$ \\
\hline & $\begin{array}{l}\text { Aparat } \\
\text { memahami } \\
\text { aturan } \\
\text { pelayanan } \\
\text { yang baik }\end{array}$ & 4,30 & 3,87 & 0,43 \\
\hline & Rata-Rata & $\mathbf{4 , 3 9}$ & $\mathbf{4 , 3 4}$ & $\mathbf{0 . 2 2}$ \\
\hline
\end{tabular}

Sumber: Hasil Pengolahan Data

Dari hasil penelitian, dua indikator dalam dimensi reliability sesuai dengan harapan pelanggan dan dua indikator tidak ada yang sesuai dengan harapan Pelanggan. Dua indikator yang melampaui harapan pelanggan ialah proses pelayanan cepat dan tepat serta aparat memahami aturan pelayanan yang baik. Gap dari indikator pemahaman aparat terhadap peraturan cukup besar besar yaitu 0,43, artinya aparat sungguh-sungguh telah memahami aturan yang ada, sedangkan gap proses pelayanan yang cepat sudah sesuai dengan harapan pelanggan, dan sedikit melampaui harapan yakni 0,02 .

Dua indikator berikutnya ialah indokator prosedur pelayanan mendapatkan nilai $-0,22$ yang berarti ada beberapa perubahan yang perlu dilakukan pada prosedur layanan, sedangkan pada indikator rincian biaya sudah mendekati harapan pelanggan, hanya sedikit perbedaan (gap) saja yakni -0,01.Melihat hasil angka gap/kesenjangan di atas, nampaknya tidak terlalu banyak perubahan pada dimensi realibility yang harus dibenahi agar sesuai dengan harapan pelanggan. Yang perlu untuk diperhatikan hanyalah prosedur pelayanan yang walaupun angkanya cukup tinggi tapi masih dibawah 0,50 . 


\section{Dimensi Responsiveness}

Tabel 4.7. Kesenjangan antara Persepsi dan Harapan Dimensi Responsiveness

\begin{tabular}{|c|c|c|c|c|}
\hline \multirow[b]{2}{*}{ No } & \multirow[b]{2}{*}{ Indikator } & \multicolumn{2}{|l|}{ Skor } & \multirow[b]{2}{*}{ Gap } \\
\hline & & Persepsi & Harapan & \\
\hline 1 & \begin{tabular}{lr}
\multicolumn{2}{l}{ Petugas memberikan } \\
Pelayanan & yang \\
berkualitas & pada \\
pelanggan &
\end{tabular} & 4,33 & 4,67 & $-0,34$ \\
\hline 2 & $\begin{array}{l}\text { Petugas repat } \\
\text { tanggap terhadap } \\
\text { segala masalah yang } \\
\text { disampaikan } \\
\text { langsung }\end{array}$ & 4,43 & 4,66 & $-0,23$ \\
\hline 3 & $\begin{array}{lr}\text { Petugas } & \text { cepat } \\
\text { tanggap } & \text { terhadap } \\
\text { keluhan pelanggan } \\
\text { yang disampaikan } \\
\text { pada kotak saran }\end{array}$ & 4,05 & 4,75 & $-0,70$ \\
\hline 4 & $\begin{array}{lr}\text { Petugas } & \text { segera } \\
\text { mengubah pelayanan } \\
\text { yang buruk yang } \\
\text { dikritisi } & \text { oleh } \\
\text { pelanggan } & \end{array}$ & 3,87 & 3,68 & 0,19 \\
\hline & Rata-rata & 4,17 & 4.44 & -1.08 \\
\hline
\end{tabular}

Sumber: Hasil Pengolahan Data

Seperti yang terlihat pada tabel di atas, gapgap pada dimensi responsiveness ini walaupun tidak terlihat terlihat cukup jauh antara persepsi dan harapan pelanggan, pada indikator sikap Petugas cepat tanggap terhadap keluhan pelanggan yang disampaikan pada kotak saran, gap-nya mencapai 0,70 . Bila dihubungkan dengan dimensi tangible aset yakni ketersediaan kotak saran, maka dapat dianalisis, yakni responden memberikan skor yang baik terhadap ketersediaan kotak saran, tetapi yang perlu disadari bahwa respon dari petugas terhadap saran pelanggan belum dapat terealisir dengan baik.
Hal ini tentu saja berhubungan dengan indoktor kedua pada dimensi realibiliy ini, dimana indikator gap juga terlihat dengan nilai $-0,23$ pada cepat tanggapnya petugas terhadap segala masalah yang disampaikan langsung.

Pelayanan yang diberikan petugas mendapatkan angka gap di bawah harapan pelanggan sebanyak $-0,34$. Walaupun gap nilai masih di bawah 0,50 , tapi hal ini menunjukkan perlu adanya perhatian dari petugas di masa yang akan datang.

Pada dimensi realibility ini Pelanggan melihat adanya usaha yang sungguh-sungguh dari petugas untuk mengubah yang buruk. Hal ini terlihat dari penilaian responden dimana ada gap harap sebanyak 0,19 , yang mengandung arti pelanggan memberikan tanggapan positif atas usaha yang telah dilakukan petugas. Tidak jauh berbeda dengan dimensidimensi yang lain, dalam dimensi responsiveness ini kinerja petugas pajak di Pelayanan Jasa Teknologi di B2TKS - BPPT, walaupun tiga indikator yang ada pada dimensi ini masih di bawah harapan Pelanggan, tapi nilainya gapnya tidak begitu tinggi dan masih pada batas toleransi.

\section{Dimensi Assurance}

Tabel 4.8. Kesenjangan antara Persepsi dan Harapan Dimensi Assurance

\begin{tabular}{|c|c|c|c|c|}
\hline \multirow[b]{2}{*}{ No } & \multirow[b]{2}{*}{ Indikator } & \multicolumn{2}{|l|}{ Skor } & \multirow[b]{2}{*}{ Gap } \\
\hline & & Persepsi & Harapan & \\
\hline 1 & $\begin{array}{l}\text { Keramahan } \\
\text { petugas dalam } \\
\text { pelayanan } \\
\text { terhadap } \\
\text { pelanggan }\end{array}$ & 4,20 & 4,68 & $-0,48$ \\
\hline 2 & $\begin{array}{l}\text { Kesopanan } \\
\text { petugas dalam } \\
\text { pelayanan } \\
\text { terhadap } \\
\text { pelanggan }\end{array}$ & 4,25 & 4,68 & $-0,43$ \\
\hline 3 & $\begin{array}{l}\text { Terlihat } \\
\text { keharmonisan }\end{array}$ & 4,38 & 4,68 & $-0,30$ \\
\hline
\end{tabular}




JURNAL ILMIAH
\begin{tabular}{|l|l|l|l|l|}
\hline & $\begin{array}{l}\text { Pubungan antar } \\
\text { pegawai }\end{array}$ \\
\hline 4 & $\begin{array}{l}\text { Ketepatan dan } \\
\text { ketegasan } \\
\text { aparatur dalam } \\
\text { menerapkan } \\
\text { peraturan }\end{array}$ & 4,33 & 4,79 & $-0,46$ \\
\hline & Rata-Rata & 4,29 & 4,71 & -1.67 \\
\hline
\end{tabular}

Dari hasil pengolahan data, tingkat kesenjangan pada dimensi assurance semua masih dibawah harapan pelanggan. Gap yang tertinggi adalah pada indikator sikap Keramahan petugas dalam pelayanan terhadap pelanggan, yaitu sebesar 0,48. Demikian juga pada sikap Ketepatan dan ketegasan aparatur dalam menerapkan peraturan mempunyai kesenjangan sebesar -0,06. Indikator Kesopanan petugas dalam pelayanan terhadap pelanggan mempunyai gap sebesar $-0,43$. Dalam keharmonisan hubungan antar pegawai besarnya kesenjangan adalah $-0,30$.

Dari hasil pengolahan data, tingkat kesenjangan pada dimensi assurance semua masih dibawah harapan pelanggan. Gap yang tertinggi adalah pada indikator sikap Keramahan petugas dalam pelayanan terhadap pelanggan, yaitu sebesar 0,48. Demikian juga pada sikap Ketepatan dan ketegasan aparatur dalam menerapkan peraturan mempunyai kesenjangan sebesar $-0,06$. Indikator Kesopanan petugas dalam pelayanan terhadap pelanggan mempunyai gap sebesar $-0,43$. Dalam keharmonisan hubungan antar pegawai besarnya kesenjangan adalah $-0,30$.

Menanggapi dimensi ini, Pelayanan Jasa Teknologi di B2TKS - BPPT harus berusaha menjaga mutu pelayanan sebaik mungkin. Hal inilah yang membuat Pelanggan menilai bahwa kinerja petugas yang perlu menungkatkan keharmonisan antar petugas sehingga terlihat profesional.

Dari hasil pengolahan data, tingkat kesenjangan pada dimensi assurance semua masih dibawah harapan pelanggan. Gap yang tertinggi adalah pada indikator sikap Keramahan petugas dalam pelayanan terhadap pelanggan, yaitu sebesar 0,48. Demikian juga pada sikap Ketepatan dan ketegasan aparatur dalam menerapkan peraturan mempunyai kesenjangan sebesar $-0,06$. Indikator Kesopanan petugas dalam pelayanan terhadap pelanggan mempunyai gap sebesar $-0,43$. Dalam keharmonisan hubungan antar pegawai besarnya kesenjangan adalah $-0,30$. 


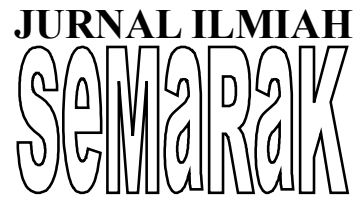

Dari hasil pengolahan data, tingkat kesenjangan pada dimensi assurance semua masih dibawah harapan pelanggan. Gap yang tertinggi adalah pada indikator sikap Keramahan petugas dalam pelayanan terhadap pelanggan, yaitu sebesar 0,48 . Demikian juga pada sikap Ketepatan dan ketegasan aparatur dalam menerapkan peraturan mempunyai kesenjangan sebesar -0,06. Indikator Kesopanan petugas dalam pelayanan terhadap pelanggan mempunyai gap sebesar $-0,43$. Dalam keharmonisan hubungan antar pegawai besarnya kesenjangan adalah $-0,30$.

Menanggapi dimensi ini, Pelayanan Jasa Teknologi di B2TKS - BPPT harus berusaha menjaga mutu pelayanan sebaik mungkin. Hal inilah yang membuat Pelanggan menilai bahwa kinerja petugas yang perlu menungkatkan keharmonisan antar petugas sehingga terlihat profesional.

\section{Dimensi Empathy}

Tabel 4.9. Kesenjangan antara Persepsi dan Harapan Dimensi Empathy

\begin{tabular}{|c|c|c|c|c|}
\hline \multirow[b]{2}{*}{ No } & \multirow[b]{2}{*}{ Indikator } & \multicolumn{2}{|l|}{ Skor } & \multirow[b]{2}{*}{ Gap } \\
\hline & & Persepsi & Harapan & \\
\hline 1 & $\begin{array}{l}\text { Kemauan petugas } \\
\text { untuk } \\
\text { mendengarkan } \\
\text { keluhan pelanggan }\end{array}$ & 4,36 & 4,78 & $-0,42$ \\
\hline 2 & $\begin{array}{l}\text { Kemauan petugas } \\
\text { untuk mencatat } \\
\text { semua keluhan }\end{array}$ & 4,44 & 4,16 & 0,28 \\
\hline 3 & $\begin{array}{l}\text { Keinginan yang } \\
\text { kuat dari petugas } \\
\text { untuk } \\
\text { mensosilalisikan } \\
\text { pelayanan pada } \\
\text { pelanggan }\end{array}$ & 4,37 & 4,87 & $-0,50$ \\
\hline 4 & $\begin{array}{l}\text { Terlihat adanya } \\
\text { Kemauan Petugas } \\
\text { untuk berusaha } \\
\text { lebih baik dalam }\end{array}$ & 4,41 & 4,14 & 0,27 \\
\hline
\end{tabular}

\begin{tabular}{|l|l|l|l|l|}
\hline & pelayanan & & & \\
\hline & Rata-Rata & 4,40 & 4.49 & -0.37 \\
\hline
\end{tabular}

Sumber: Hasil Pengolahan Data

Pada dimensi empathy ini, kesenjangan yang ada dapat terlihat lebih menggembirakan dibanding dengan dimensi-dimensi yang lain, meskipun ada indikator yang masih di bawah harapan Pelanggan. Skor-skor persepsinya juga lebih tinggi apabila dibandingkan dengan dimensi-dimensi yang lain. Pada indikator Kemauan petugas untuk mencatat semua keluhan, mempunyai gap yang tinggi dan melampaui persepsi pelanggan, yaitu sebesar 0,28. Demikian pula adanya Kemauan Petugas untuk berusaha lebih baik dalam pelayanan melampaui persepsi pelanggan dengan gap sebesar 0,27 . Tetapi dua indikator lagi memiliki skor negatif yakni Kemauan petugas untuk mendengarkan keluhan pelanggan $(-0,42)$ dan Keinginan yang kuat dari petugas untuk mensosilalisikan pelayanan pada pelanggan $(-0,50)$.Hal ini mengandung arti petugas hanya mau mencatat, namun masih kurang dalam penilaian mendengar dan memberikan informasi.

Kinerja petugas Pelayanan Jasa Teknologi di B2TKS - BPPT dalam dimensi ini cenderung lebih baik dibandingkan dengan dimensidimensi yang lain. Sikap petugas di nilai sudah cukup baik dalam melayani Pelanggan, tetapi sikap Pelanggan dalam menangani keluhan Pelanggan harus diperbaiki lagi, terutama dalam menyampaikan informasi mengingat indikator tersebut mempunyai gap yang paling besar dalam dimensi ini, sehingga Pelanggan bisa lebih puas dalam menerima pelayanan petugas.

\subsubsection{Analisis Kepuasan Pelanggan atas}

\section{PelayananJasa Teknologi di B2TKS}

Tolok ukur kualitas pelayanan yang diberikan oleh Pelayanan Jasa Teknologi di B2TKS - BPPT adalah tingkat kepuasan Pelanggan atas pelayanan yang nyata-nyata diterima (persepsi) dan pelayanan yang Pelanggan harapkan. Apabila persepsi Pelanggan dibawah harapan, maka Pelanggan tidak puas terhadap pelayanan yang 


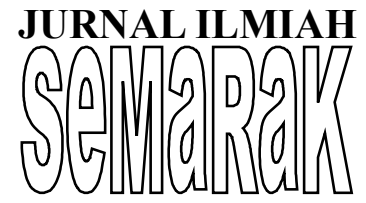

diberikan. Apabila persepsi sama dengan harapan, maka Pelanggan puas akan pelayanan yang diberikan. Apabila tingkat persepsi di atas harapan, maka Pelanggan puas akan pelayanan yang telah merekan terima. Dibawah ini adalah secara total akhirnya dapat diketahui total gap (kesenjangan) mengenai tingkat kepuasan para pengguna layananatas pelayanan yang diberikan oleh pegawai bagian Pelayanan Jasa Teknologi di B2TKS - BPPT

Atas penelitian yang telah dilakukan, terlihat bahwa gap total adalah $-2,84$ yang mengandung arti bahwa Pelayanan Jasa Teknologi di B2TKS - BPPT perlu untuk diperbaiki. Secara dimensi perbaikan pada dimensi responsiveness dan assurance karena memiliki skor gap -1,08 dan - 1,67, sedangkan skor yang lain berada di bawah 0,50. Namun secara indikator, maka fokus peningkatan pelayanan terhadap pelanggan yang perlu mendapat perhatian terlihat pada indikator sebagai berikut; yaitu petugas belum cepat tanggap terhadap keluhan pelanggan yang disampaikan pada kotak saran $(-0,70)$, Keinginan yang kuat dari petugas untuk mensosilalisikan pelayanan pada pelanggan $(-0,50)$ serta Keramahan petugas dalam pelayanan terhadap pelanggan $(-0,48)$.

\section{BAB V}

\section{KESIMPULAN DAN SARAN}

\section{A. Kesimpulan}

Berdasarkan penelitian yang dilakukan, maka dapat dirumuskan kesimpulan berdasarkan tujuan yang ingin dicapai sebagai berikut:

1. Hasil penelitian menunjukkan bahwa persepsi responden yang menerima pelayanan yang diberikan oleh B2TKS BPPT dinilairata-rata di atas angka 4,34 (di atas baik). Hal ini ditunjukkan denganhasil pengolahan data dari 5 dimensi dan 20 indikator yang diajukan.Sebagian besar responden menjawab sangat setuju dan setuju. Apa bila dilihat menurut dimensi, maka dimensi yang dinilai paling baik secara berturut-turut oleh responden adalah tangibles, empathy, reliability, assurance dan responsiveness.
2. Dari hasil pengolahan data penelitian, responden mempunyai harapan yang lebih tinggi dari persepsi atas pelayanan yang diberikan oleh Kantor B2TKS - BPPT. Hal inidibuktikandari skor rata-rata nilai harapan ialah $4,49>4,34$. Namun bila dilihat menurut dimensinya, maka harapan responden yang dinilai tertinggi secara berturut-turut adalah Responsiveness, Empathy, Tangibles, Assurance dan Reliability.

3. Berdasarkan hasil penelitian, maka kualitas pelayanan yang diberikan oleh B2TKS BPPTsudah dinilai berjalan pada harapan responden. Hal inidapat terlihat dari beberapa indikator yang berada di atas harapan pelanggan. Namun kesenjangan terjadi pula pada sebagian indikator yang harus segera diperbaiki. Indikator yang perlu mendapatkan perhatian penting yang berada dibawah harapan pelanggan ialah pada dimensi tangible (Jumlah, jenis dan kondisi peralatan kerja), pada dimensi reliability (peningkatan pemahaman aturan pelayanan yang lebih baik); responsiveness (petugas belum cepat tanggap terhadap keluhan pelanggan yang disampaikan pada kotak saran); assurance (peningkatan keramahan dan kesopanan Keramahan petugas dalam pelayanan terhadap pelanggan) serta empathy (mensosilalisikan pelayanan pada pelanggan dengan cepat).

\section{B. Saran}

Beberapa saran yang dapat dijadikan masukan bagi B2TKS - BPPT berkaitan dengan kualitas pelayanan, dengan mengacu pada hasil penelitian atas 5 dimensi kualitas pelayanan adalah :

1. B2TKS - BPPT, perlu melengkapi peralatan pelayanan publik yang lebih baik lagi dibandingkan dengan yang ada saat ini.

2. Perlu diadakan pelatihan lanjutan terhadap petugas pelayanan, terutama untuk mengatisipasi keramahan dan ketanggapan dalam melayani para pelanggan, sehingga kualitas pelayanan dapat lebih ditingkatkan

\section{DAFTAR PUSTAKA}




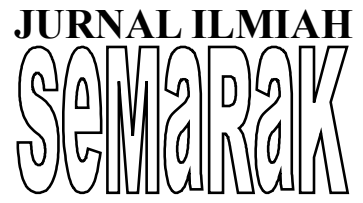

Arikunto, Suharsimi. 2003. Prosedur Penelitian: Suatu pendekatan Praktek. Jakarta: Rineka Cipta.

B. Boediono, Pelayanan Prima Perpajakan, Jakarta, 2003.

Catherine De Vrye, Good Service is Good Business, terjemahan M.Prihminto Widodo, Jakarta: PT. GramediaPustaka Utama, 1997.

Daviddow, William, and Uttal, Total Customer Service The Ultimate Weapon, 1989.

Davis, Keith, \& John W. Newstrom. 1985. Perilaku Dalam Organisasi. Jilid 1. Edisi Ketujuh. Jakarta: Erlangga.

David Osborne \& Ted Gaebler, Mewirausahakan Birokrasi (Reinventing Government). Jakarta : Teruna Grafica

Fandy Tjiptono \& Anastasia Diana. Total Quality Management. Edidi Revisi. Yogyakarta; Andi.

Gibson, Ivancevich and Donely. 1992. Organisasi dan Manajemen: Perilaku, Struktur, dan Proses. Jakarta: Erlangga.

Handoko, T. Hani. 2002. Manajemen Personalia dan Sumber daya Manusia. Yogyakarta: BPFE.

Handari Nawawi. M. Martini Handani. Kepemimpinan Yang Efektif. Yogyakarta: Gajah Mada University Press.

Hasibuan, Malayu S. P. 2001. Manajemen Sumber Daya Manusia: Dasar dan Kunci Keberhasilan. Jakarta: Haji Masagung.

Hersey, Paul, dan Kenneth H. Blanchard. 1998. Management of Organizational Behavior: Utilizing Human Resources. New Jersey: Pretince Hall, Inc.
Hessel Nogi Tangkilisan, 2007, Manajemen Publik. Jakarta: Grasindo.

Johannes, Basuki. 1997. Budaya Organisasi (Konsep dan Terapan). Jakarta: Yayasan Pembina Manajemen.

Joewono, FX. Herry. 2002, Pokok-Pokok Pikiran Kepemimpinan Abad 21, Jakarta: Balai Pustaka.

Kast E, Fremont and Rosenzweig E. 1986. Organization and Management. Jakarta: Bina Aksara

Karl Albrecht, Service Within Business, Illionis, 1990.

Kenneth. N. Wexley \& Gary A. Yuki. 2005. Perilaku Organisasi dan Psikologi Personalia. Jakareta: Rineka Cipta.

Koontz, Harold. 1996. Management. Tokyo: McGraw-Hill, Kogakusha.

Knootz Harold/Cyriil O'Donnell/Heinz Weihrich. 1990. Management. Jakarta: Erlangga.

Lembaga Administrasi Negara. 1997. Sistem Administrasi Negara Republik Indonesia. Jakarta: Toko Gunung Agung.

Mangkuprawira, Tb. Sjafri. 2004. Manajemen Sumber Daya Manusia Strategik. Jakarta: Ghalia Indonesia.

Manullang, M. 1991. Management Personalia. Jakarta: Ghalia Indonesia.

Maslow, Abraham H. 1992. Motivation and Personality. Tokyo: McGraw-Hill, Inc.

Moe Heriono. 2009. Pengukuran Kinerja Berbasis Kompetnsi: Jakarta: Ghalia Indonesia

Rivai, Veithzal. 2005. Manajemen Sumber Daya Manusia untuk Perusahaan: Dari Teori ke Praktik. Jakarta: Rajagrafindo Persada. 
Richard Normann, Service Management Strategy and Leadership in Service Business, 1991.

Robbins, Stephen P. 1994. Teori Organisasi: Struktur, Desain, dan Aplikasi. Jakarta: Arcan.

Sugiyono, 2009. Metode Penelitian

Administrasi, dilengkapi dengan Metode R\&D. Bandung : CV Alfabeta

Pasaribu, V. L. D. P. D. (2018). PENGARUH BIAYA PROMOSI TERHADAP PENINGKATAN PENJUALAN KARTU FLEXI PT. TELEKOMUNIKASI SELULER (TELKOMSEL) JAKARTA (Studi kasus Produk Kartu Flexi Pt. Telkomsel. Jakarta Selatan). JURNAL PEMASARAN KOMPETITIF, 1(2).

Pasaribu, V. L. D., \& Prayoga, M. Y. S. (2019). PENGARUH KUALITAS PRODUK BAJU BATIK HEM TERHADAP KEPUASAN PELANGGAN PADA HOME INDUSTRI BATIK SAHARA INDAH. JURNAL PEMASARAN KOMPETITIF, 2(2), 77-83. 